\title{
Chagas cardiomyopathy and serologic testing in a small rural hospital in Chiapas, Mexico
}

\author{
Linnea Capps ${ }^{1}$ and Begoña Abad²
}

Suggested citation Capps L, Abad B. Chagas cardiomyopathy and serologic testing in a small rural hospital in Chiapas, Mexico. Rev Panam Salud Publica. 2004;15(5):337-40.

ABSTRACT Objectives. To conduct a study in a small rural hospital located in the state of Chiapas, Mexico, to: (1) examine the prevalence of chagasic cardiomyopathy among patients with the diagnosis of congestive heart failure and (2) assess the prevalence of positive serologic results in blood donors in the hospital, in an attempt to ascertain whether Chagas' disease remains an important cause of heart failure at least in some areas of Mexico.

Methods. The study of patients with cardiomyopathy was conducted by retrospective chart review of patients with the diagnosis of congestive heart failure treated at the hospital during the years 2000-2002. With the blood donors, the results of their serologic screening were reviewed for a six-month period beginning in April 2002. Serologic testing was done in both groups with either indirect hemagglutination (IHA) or enzyme-linked immunosorbent assay (ELISA), or with both.

Results. Of 67 patients with heart failure and no risk factors for other causes of heart failure, 40 of them had serologic tests performed. Thirty-three of these 40 (82.5\%) were positive by ELISA, IHA, or both. With 97 blood donors, one or both serologic tests were positive in 17 of them $(17.5 \%)$.

Conclusions. This research adds to the evidence that Chagas' disease continues to be a major cause of heart failure in some areas of Mexico and that there continues to be a risk of transmission by blood transfusion if donated blood is not consistently screened.

Key words Chagas disease, Chagas cardiomyopathy, Trypanosoma cruzi, electrocardiography, seroepidemiologic studies, Mexico.

Chagas' disease occurs throughout Latin America and remains a major public health concern in many areas.

\footnotetext{
1 Columbia University College of Physicians and Surgeons/Harlem Hospital, Department of Internal Medicine, New York, New York, United States of America. Send correspondence to: Linnea Capps, Department of Medicine, Harlem Hospital, 506 Lenox Avenue, Room 14101, New York, New York 10037, United States of America; e-mail: 1c9@columbia.edu; telephone: 212-939-1423; fax: 212-939-1403.

2 Hospital San Carlos, Department of Internal Medicine, Altamirano, Chiapas, Mexico.
}

Efforts by governments and the World Health Organization (WHO) in several countries in South America have resulted in important reductions in transmission of Trypanosoma cruzi, especially in children (1). However, the disease remains endemic in various parts of Latin America, including the Andean countries, Central America, and several areas of Mexico. Many rural areas have not been adequately studied, and the incidence remains unknown in some areas. A WHO expert committee recently estimated that 8-9 million people in Mexico, Central America, and the Andean region of South America are infected and that 25 million persons remain at risk (2).

Established infection with T. cruzi is chronic and incurable. In many rural areas of Latin America it is a major cause of heart failure, and it can also cause gastrointestinal and neurologic damage. Disease manifestations vary greatly from one endemic area to another. In Central America and Mexico 
the most important long-term morbidity is cardiomyopathy. Chagasic cardiomyopathy may be an important cause of heart failure in many regions of Mexico but is probably underreported because the clinical signs are nonspecific. However, the disease can be suspected clinically by the presenting signs and symptoms of heart failure and by electrocardiographic manifestations. The pathophysiologic features include interstitial fibrosis of the myocardium and dilatation and thinning of the ventricular wall, involving the right ventricle more than the left. The fibrosis also affects the conduction system, the right bundle of His more often than the left. Thus, it often presents with signs of rightsided heart failure and right bundle branch block on electrocardiogram.

Mexico has only recently begun to develop a comprehensive public health program to address Chagas' disease. More epidemiologic surveillance and vector control programs are being considered, and in 2001 the Secretariat of Health approved regulations that mandated screening of all blood donors for Chagas' disease. However, it is not clear whether all hospitals, especially small rural ones, have been able to consistently screen all donated blood.

A number of studies of the prevalence of Chagas' disease have been reported over the last decade in Mexico (3-7). Some have been populationbased studies of the prevalence of positive serologic results. They present a picture of a very heterogeneous distribution of infection, with some very highly endemic rural areas and virtually disease-free urban zones. A major limitation of many of the studies, especially older ones, is the use of a single serologic test. The current $\mathrm{WHO}$ recommendations are that two different tests should be used since there are significant numbers of false positives and false negatives.

Mexico's National Seroepidemiology Survey of 1987 found prevalence levels ranging from a low of $0.1 \%$ in the state of Jalisco to a high of $5.0 \%$ in the state of Chiapas (4). A major limitation of this large study was its poor coverage of rural areas, which probably led to a sig- nificant underestimation of the prevalence in the rural population. Chiapas is located in southern Mexico, on the border with Guatemala, and it is one of the poorest states in Mexico. It has a large rural indigenous population. The majority of the rural population is poor, and many live in substandard housing where the insect vectors can multiply, placing the inhabitants at risk for transmission of the disease.

A recent serologic survey in four different geographic zones in Chiapas sampled 1333 residents in 13 communities (8). Prevalence was high in the Lacandon Forest and Central Mountain regions $(32.1 \%$ and $13.8 \%$, respectively). Those authors noted that there apparently continues to be active transmission since seropositive cases were found in children under 10 years of age.

A few studies have reported the number of cases of chagasic cardiomyopathy within a patient population with cardiac disease. However, there is very little epidemiologic data on the incidence of chronic Chagas' disease. A recent review of data on Chagas' disease in Mexico concluded that information on the prevalence of the disease is scarce. Over a five-year period in the mid-1990s, 441 new cases of chronic chagasic cardiomyopathy were reported to health authorities in Mexico (9). This has led some to conclude that Mexican strains of T. cruzi have low virulence, but lack of detection of existing cases could certainly be the explanation as well. A study published in 1995 found that 7 of $36(19.4 \%)$ cases of heart disease in a hospital in the city of Mérida, Yucatán, were caused by Chagas' disease (10). Another study, in Mexico City, found that 21 of 40 (52.5\%) patients with dilated cardiomyopathy were seropositive for T. cruzi (11).

We report a case series of chagasic cardiomyopathy from a small rural hospital in Chiapas and data on the prevalence of positive Chagas serologic results in blood donors from the same hospital. Our impression, formed by caring for patients with heart failure, was that Chagas' disease continues to be an important cause of heart failure in rural areas such as Chiapas. The review of these cases was under- taken in an attempt to assess whether that supposition was valid or not. In addition, we wanted to evaluate the prevalence of seropositivity in healthy blood donors.

\section{METHODS}

We reviewed all the records of patients in a small rural hospital for the diagnosis of congestive heart failure. The hospital has an average of 2500 hospital discharges per year and 12000 to 14000 outpatient visits per year. The patients come from a wide area of the state of Chiapas, and the vast majority of them are indigenous Mayans.

We selected for review all the charts of patients with a diagnosis of congestive heart failure who had been hospitalized or seen in the outpatient clinic during the years of 2000 through 2002. We collected data on serologic results and clinical signs of heart failure (jugular venous distension, rales on auscultation of the lungs, hepatomegaly, and peripheral edema). We reviewed chest $X$ rays (for cardiothoracic ratio) and electrocardiograms (for rhythm and bundle branch blocks). We also noted any diagnosis that could be a risk factor for heart failure, such as hypertension, diabetes, valvular heart disease, and alcoholism. Serologic analysis was not done in all patients before 2002 . Only the indirect hemagglutination (IHA) test was available, and it was not systematically done in all patients with heart failure. The enzyme-linked immunosorbent assay (ELISA) was not available until April 2002. We attempted to do both serologic tests in patients who were seen after that date.

Starting in April 2002, the hospital screened all donated blood with serologic tests, using the same two tests. We reviewed the results of this screening for six months, starting in April 2002.

The indirect hemagglutination was conducted using kits from Wiener Laboratorios (Rosario, Argentina). Specimens were treated with 2mercaptoethanol (2-ME) at a dilution of 1:40, according to the manufacturer's instructions. A titer of 1:16 was considered a positive result. The 
ELISA used was a commercially available kit, also from Wiener; this test is reported to have a sensitivity of $100 \%$ and specificity of $99.6 \%$.

\section{RESULTS}

\section{Patients with congestive heart failure}

A total of 78 patients with the diagnosis of congestive heart failure were identified. Of these 78, 11 of them had other conditions that could cause heart failure and so were excluded from the data reported here. These 11 included 3 with hypertension, 2 with diabetes, 2 with valvular heart disease, 2 with cor pulmonale, 1 with a history of alcoholism, and 1 with severe anemia.

Among the 67 patients with heart failure, there were 36 women and 31 men. The mean age was 60.3 , with a range of 25 to 99 . Forty-three percent were under 60 years of age.

Fifty-four patients had chest $X$ rays done. All of these persons had cardiomegaly, with a mean cardiothoracic ratio of 0.68 and a range of 0.51 to 0.84 . Of the 56 patients with electrocardiograms, only 5 had left ventricular hypertrophy. Thirty-five had atrial fibrillation, and 21 had right bundle branch block. The most common clinical signs were those of right-sided heart failure (hepatomegaly and jugular venous distention) or biventricular failure. Only 4 patients had signs of pulmonary edema without signs of right-sided failure.

Of the 67 patients, 40 of them had serologic testing performed. One or both tests were positive in 33 of those 40 patients $(82.5 \%)$. Both serologic tests were done in 13 of the 40 patients $(32.5 \%)$. ELISA was positive in 12 of the 13 , and indirect hemagglutination positive in all 13 of them. An additional 20 patients who were tested before the ELISA became available had positive indirect hemagglutination results (Table 1).

\section{Blood donors}

A total of 97 blood donors were screened during the six-month period from April to September of 2002, using
TABLE 1. Results of Chagas serologic testing in 67 patients with cardiomyopathy, Chiapas, Mexico, 2000-2002

\begin{tabular}{|c|c|c|c|c|c|}
\hline \multirow[b]{3}{*}{ Test } & \multirow{3}{*}{$\begin{array}{l}\text { Testing } \\
\text { not done }\end{array}$} & \multicolumn{4}{|c|}{ Test result } \\
\hline & & \multicolumn{2}{|c|}{ Positive } & \multicolumn{2}{|c|}{ Negative } \\
\hline & & No. & $\%$ & No. & $\%$ \\
\hline Enzyme-linked immunosorbent assay (ELISA) & 54 & 12 & 92.3 & 1 & 7.7 \\
\hline Indirect hemagglutination $(\mathrm{IHA})$ & 27 & 33 & 82.5 & 7 & 17.5 \\
\hline
\end{tabular}

IHA with 97 of them and the ELISA with 69 of them. Of those 97, 85 were men and 12 were women. The mean age was 32.8 , with ages ranging from 18 to 54. Seventeen of these 97 (17.5\%) were positive by one or both tests. Of these 17,7 of them $(41.2 \%)$ were less than 30 years old. ELISA was positive in 7 of 69 patients $(10.1 \%)$ tested with both types of serologic analysis (Table 2).

\section{DISCUSSION}

In this series of patients with congestive heart failure in one small hospital in the state of Chiapas, Mexico, a very high proportion had serologic evidence of Chagas' disease. A substantial number of the others had clinical signs compatible with chagasic cardiomyopathy (right-sided heart failure and atrial fibrillation or right bundle branch block on electrocardiogram) and no history of other risk factors for congestive heart failure. Hypertension is uncommon in this patient population, and patients with a history or electrocardiographic findings that suggest ischemic heart disease are very rare.

These data suggest that Chagas' disease is still a common cause of conges- tive heart failure in some areas of Mexico. It seems more likely that many cases of chronic Chagas' disease are unrecognized rather than that the strains of T. cruzi found in Mexico are less virulent than those in other parts of Latin America.

Our study is limited by the fact that it is a case series from one small hospital and that we do not have serologic testing results on all the patients in the series. In addition, we have two serologic tests on only a part of our sample.

Despite the limitations, this series adds to the evidence that Chagas' disease continues to be a major cause of heart failure at least in some areas of Mexico, particularly poor rural regions such as Chiapas. In addition, the high rate of seropositivity in blood donors, many of whom are young adults, suggests that transmission by insect vectors is probably continuing and that there is a risk of transmission by blood transfusion if donated blood is not screened. Prevention of new cases of Chagas' disease, and of the disability and premature death that it causes, will require not only more consistent screening of donated blood but also greater attention to public health measures to reduce transmission.
TABLE 2. Results of Chagas serologic testing in 97 blood donors, Chiapas, Mexico, 2002

\begin{tabular}{|c|c|c|c|c|c|}
\hline \multirow[b]{3}{*}{ Test } & \multirow{3}{*}{$\begin{array}{l}\text { Testing } \\
\text { not done }\end{array}$} & \multicolumn{4}{|c|}{ Test result } \\
\hline & & \multicolumn{2}{|c|}{ Positive } & \multicolumn{2}{|c|}{ Negative } \\
\hline & & No. & $\%$ & No. & $\%$ \\
\hline Enzyme-linked immunosorbent assay (ELISA) & 28 & 7 & 10.1 & 62 & 89.9 \\
\hline Indirect hemagglutination (IHA) & 0 & 14 & 14.4 & 83 & 85.6 \\
\hline
\end{tabular}




\section{REFERENCES}

1. Schofield CJ, Dias JC. The Southern Cone Initiative against Chagas disease. Adv Parasitol. 1999;42:1-27.

2. World Health Organization. Control of Chagas disease. Geneva: WHO; 2002. (WHO Technical Report Series no. 905).

3. Ruegsegger de Gutiérrez GL, Monteón VM, Marcuschamer J, Reyes PA. Trypanosomiasis americana. Estudio clínico-serológico en una comunidad rural en el estado de Oaxaca. Arch Inst Cardiol Mex. 1993;63(2):145-8.

4. Velasco-Castrejón O, Valdespino JL, TapiaConyer R, Salvatierra B, Guzmán-Bracho C, Magos C, et al. Seroepidemiología de la enfermedad de Chagas en México. Salud Publica Mex. 1992;34(2):186-96.

5. Trujillo Contreras F, Lozano Kasten F, Soto Gutiérrez MM, Hernández Gutiérrez R. Prevalencia de infección a Trypanosoma cruzi en donadores de sangre en el estado de Jalisco,
México. Rev Soc Bras Med Trop. 1993;26(2): 89-92.

6. Trujillo Contreras F, Villanueva Yerenas M, Soto Gutiérrez M, Raygoza Anaya M, Jiménez Corder A. Seguimiento serológico de la infección por Trypanosoma cruzi desde 1987 hasta 1994 en personas estudiadas en 50 municipios del Estado de Jalisco, México. Rev Soc Bras Med Trop. 2000;33(6):591-6.

7. Rangel-Flores H, Sánchez B, Mendoza-Duarte J, Barnabé C, Brenière FS, Ramos C, et al. Serologic and parasitologic demonstration of Trypanosoma cruzi infections in an urban area of central Mexico: correlation with electrocardiographic alterations. Am J Trop Med Hyg. 2001;65(6):887-95.

8. Mazariego-Arana MA, Monteón VM, Ballinas-Verdugo MA, Hernández-Becerril N, Alejandre-Aguilar R, Reyes PA. Seroprevalence of human Trypanosoma cruzi infection in different geographic zones of Chiapas, Mexico. Rev Soc Bras Med Trop. 2001;34(5):453-8.

9. Dumonteil E. Update on Chagas' disease in Mexico. Salud Publica Mex. 1999;41(4):322-7.

10. Zavala-Castro JE, Gutiérrez-Flota H, BarreraPérez MA, Bolio-Solís DJ, Zavala-Velázquez JE. Cardiopatía chagásica detectada en pacientes del Hospital General Regional O’Horan, Mérida, Yucatán, México. Arch Inst Cardiol Mex. 1995;65:541-5.

11. Montenegro-Valdovinos PC, de Micheli A, Reyes-López PA. Hallazgos electrovectorcardigográficos en la miocardiopatía chagásica crónica. Arch Inst Cardiol Mex. 1998;68:51-7.

Manuscript received 7 May 2003. Accepted for publication on 6 November 2003.

RESUMEN Objetivo. Llevar a cabo un estudio en un hospital rural pequeño del Estado de Chiapas, México, con el fin de: 1) examinar la prevalencia de miocardiopatía chagásica en pacientes con un diagnóstico de insuficiencia cardíaca congestiva y 2) estimar la prevalencia de positividad serológica en donantes de sangre del hospital, con objeto de determinar si la enfermedad de Chagas sigue siendo una causa importante de insuficiencia cardíaca en algunas partes de México.

Métodos. El estudio de los pacientes con miocardiopatía se llevó a cabo mediante la inspección retrospectiva de las fichas de pacientes con un diagnóstico de insuficiencia cardíaca congestiva tratados en el hospital durante el período de 2000-2002. En el caso de los donantes de sangre, los resultados de sus pruebas serológicas fueron revisados durante un período de seis meses que comenzó en abril de 2002. Los pruebas serológicas se efectuaron en ambos grupos mediante hemaglutinación indirecta (HAI) o ensayo de inmunoadsorción enzimática (ELISA), o ambos métodos.

Resultados. De 67 pacientes con insuficiencia cardíaca que no tenían factores de riesgo de sufrir otras causas de este trastorno, 40 fueron sometidos a pruebas serológicas. De estos cuarenta, $33(82,5 \%)$ tuvieron resultados positivos en el ELISA, la HAI, o ambos. Del total de 97 donantes de sangre, $17(17,5 \%)$ tuvieron una o dos pruebas con resultados positivos.

Conclusiones. Este estudio se suma a las pruebas ya existentes de que la enfermedad de Chagas sigue siendo una de las principales causas de insuficiencia cardíaca en algunas partes de México y de que sigue habiendo un riesgo de transmisión por transfusión de sangre si la sangre donada no se somete a tamizaje con regularidad. 